\title{
Rotenoid Content of Tephrosia vogelii Leaves Sprayed with Growth Regulators
}

\author{
Luis $E$. Gregory, D. K. Barnes, and R. H. Freyre ${ }^{1}$
}

INTRODUCTION

The leaves of the leguminous plant Tephrosia vogelii Hook. f. constitute a promising source of supply of the natural insecticide rotenone $(2,5$, 6). ${ }^{2}$ A breeding program was established at the Federal Experiment Station, Mayagüez, Puerto Rico, to develop Tephrosia lines with increased rotenoid content and vegetative production. Chemical assays indicated that the rotenoids in yellow senile leaves ran as much as 25-percent higher than that of mature green leaves from the same plant. It would be of significant economic importance if the rotenoid content of Tephrosia leaves could be increased at harvesttime by accelerating senescence with a chemical spray. This paper reports the results of three experiments designed to study the effects of growth regulators on leaf senescence, rotenoid content, and dryweight per unit leaf area of $T$. vogelii leaves.

\section{MATERIALS AND GENERAL METHODS}

The experiment on induction of leaf senescence with growth-regulating chemicals was conducted with 4-month-old, greenhouse-grown plants of the T. vogelii line P.I. 257533. Experiments on the effect of growth regulators on rotenoid content and on dry leaf weight were conducted in field plantings of a high-rotenoid breeding line, 6285. Seedlings were germinated in the greenhouse and 2 weeks later transplanted to a field at the Isabela Substation of the Agricultural Experiment Station of the University of Puerto Rico in May 1964. Plants were spaced on 36-inch centers.

Foliar sprays of the following growth regulators were used in these studies: 2,4-dichlorophenoxyacetic acid (2,4-D); 2,6-dichlorophenoxyacetic acid (2,6-DA); $p$-chlorophenoxyacetic acid (4-CPA); 2,4,5-trichlorophenoxyacetic acid $(2,4,5-\mathrm{T}) ; 2,4,5$-trichlorophenoxypropionic acid $(2,4,5-\mathrm{TP}) ; 2,4,6$-trichlorophenoxyacetamide $(2,4,6-\mathrm{T}$ amide); 2methoxy-3,6-dichlorobenzoic acid (dicamba); diethanolamine salt of 6-hy-

1 Plant Physiologist (present address: Plant Industry Station, Beltsville, Md. 20705); Plant Geneticist (present address: University of Minnesota, St. Paul, Minn. 55101); and Agronomist, respectively, Crops Research Division, Agricultural Research Service, U.S. Department of Agriculture, Federal Experiment Station, Mayaguiez, P.R. 00708.

2 Italic numbers in parentheses refer to Literature Cited, p. 220. 
droxy-3-(2H)-pyridazinone (MH-30). ${ }^{3}$ The butoxy ethanol ester of 2,4,5-T (4 pounds acid equivalent per gallon, 58.3 percent active ingredient) and the MH-30 were dissolved directly in water. Dicamba was dissolved in a few drops of ethanol and added to the required amount of water. All other growth regulators were converted to the ammonium salt by adding ammonium hydroxide dropwise to the water until the chemical dissolved. The $\mathrm{pH}$ of the solutions was then adjusted to 2.6 with hydrochloric acid. Distilled water was sprayed on the control plants. As a wetting agent, 1 drop of Tween 20 was added to 1 liter ( 0.005 percent) of each solution and of the water control. A hand-sprayer with 20-ounce capacity was used to apply the solutions. To avoid cross-contamination a different sprayer was used for each chemical, and the plants were enclosed in a plastic cloth tent while being sprayed. A buffer plant was left between treated plants.

Rotenoid data for each plant were based on the mean of chemical assays from duplicate samples of sixty $3 / 8$-inch leaf-disks. Rotenone, the compound of primary interest in $T$. vogelii, is usually found in combination with deguelin and occasionally with other rotenoids. A red-color test first developed by Jones (7) and later modified by Barnes and Freyre (1) was used to assay total rotenoids per unit of dry leaf weight.

The influence of foliar application of growth regulators on specific leaf weight (SLW $=$ dry weight per unit leaf area) was determined by taking duplicate samples of twenty $3 / 8$-inch diameter leaf disks from each plant before treatment and at several time intervals after treatment. Disks were punched with a cork-borer held against a rubber stopper. The disks were dried at $70^{\circ} \mathrm{C}$. for 18 hours and weighed. The data were expressed as dry leaf weight per unit area.

\section{EXPERIMENTAL PROCEDURES AND RESULTS}

\section{CHEMICAL INDUCTION OF LEAF SENESCENCE}

Leaf yellowing is usually the first visible symptom of senescence in leaves; therefore we used it as a criterion for recording induced leaf senescence. Three concentrations of each of eight growth regulators plus a water control were tested for their ability to induce leaf senescence. Twenty milliliters of solution of each treatment were sprayed on each of two plants. Visual observations were recorded 3, 7, and 28 days after treatment for degree of leaf color change, phytotoxicity to leaves, and shoot epinasty (table 1).

Leaves yellowed on plants sprayed with 2,4,5-T, 2,4 ,5-TP, 2,4-D, and dicamba; but no foliage yellowing was observed on plants sprayed with

3 Reference to trade names does not imply endorsement by the U.S. Department of Agriculture over similar products not mentioned. 
TABLE 1.-Visible effects of growth-regulator foliar sprays on $\boldsymbol{T}$. vogelii plants

\begin{tabular}{|c|c|c|c|c|}
\hline \multicolumn{2}{|c|}{ Growth regulator } & \multirow{2}{*}{$\begin{array}{c}\text { Degree of } \\
\text { leaf senescence }\end{array}$} & \multirow{2}{*}{$\begin{array}{c}\text { Degree of } \\
\text { phytotoxicity } \\
\text { to leaves }\end{array}$} & \multirow{2}{*}{$\begin{array}{l}\text { Shoot } \\
\text { epinasty }\end{array}$} \\
\hline Treatment & Concentration & & & \\
\hline & $\mathbf{M g}_{\mathrm{g}} / \mathrm{lijer}$ & Scorel & Scores & Scorts \\
\hline Water control & - & 0 & 0 & 0 \\
\hline \multirow[t]{3}{*}{$2,4,6-\mathrm{T}$ amide } & 250 & 0 & $\mathbf{0}$ & 0 \\
\hline & 500 & $\mathbf{0}$ & 0 & $\mathbf{0}$ \\
\hline & 1,000 & 0 & 0 & 0 \\
\hline \multirow[t]{3}{*}{$2,6-\mathrm{DA}$} & 250 & 0 & 0 & 1 \\
\hline & 500 & 0 & 0 & 1 \\
\hline & 1,000 & 0 & 0 & 1 \\
\hline \multirow[t]{3}{*}{ 4-CPA } & 250 & 0 & 0 & 1 \\
\hline & 500 & $\mathbf{0}$ & $\mathbf{0}$ & 1 \\
\hline & 1,000 & 0 & $\mathbf{0}$ & 1 \\
\hline \multirow[t]{3}{*}{$2,4,5-T P$} & 750 & 2 & 0 & 1 \\
\hline & 1,250 & 2 & 0 & 1 \\
\hline & 1,500 & 2 & 0 & 1 \\
\hline \multirow[t]{3}{*}{ 2,4-D } & 500 & 1 & 0 & 2 \\
\hline & 750 & 2 & 0 & 2 \\
\hline & 1,000 & 2 & 2 & 2 \\
\hline \multirow[t]{3}{*}{ Dicamba } & 1,000 & 2 & 0 & 2 \\
\hline & 1,500 & 2 & 0 & 2 \\
\hline & 2,000 & & & \\
\hline \multirow[t]{3}{*}{$2,4,5-T$} & 100 & 2 & $\mathbf{0}$ & 1 \\
\hline & 200 & 2 & 0 & 1 \\
\hline & 300 & 2 & 2 & 2 \\
\hline \multirow[t]{3}{*}{ MH-30 } & 4,500 & 0 & $\mathbf{0}$ & 0 \\
\hline & 9,000 & 0 & $\mathbf{0}$ & 0 \\
\hline & 18,000 & 0 & 0 & 0 \\
\hline
\end{tabular}

${ }^{1}$ Senescence is judged by leaf color and scored; $0=$ green, $1=$ yellow green, and $2=$ yellow.

2 Phytotoxicity of the treated leaves scored; $0=$ none, $1=$ moderate, and $2=$ severe.

Shoot epinasty scored; $0=$ none, $1=$ moderate, and $2=$ severe.

2,4,6-T amide, 2,6-DA, 4-CPA, $\mathrm{MH}-30$, or on water-sprayed control plants. The foliage of plants sprayed with dicamba, 2,4,5-T, and the two highest concentrations of $2,4-D$, yellowed as early as 72 hours after being treated. The highest concentration of 2,4-D, dicamba, and 2,4,5-T caused leaf 
burning; but none of the treatments killed the plants. The plants sprayed with 2,4-D, dicamba, and with $300 \mathrm{mg}$. per liter 2,4,5-T exhibited strong shoot epinasty. Those treated with 2,6-DA, 4-CPA, 2,4,5-TP, and the two lowest concentrations of 2,4,5-T showed a moderate shoot epinasty. No epinasty was observed in plants sprayed with 2,4,6-T amide, MH-30, or in water sprayed control plants.

\section{GROWTH REGULATORS AND LEAF ROTENOIDS}

In the first experiment it was demonstrated that some growth regulators could be used to yellow Tephrosia leaves. A second experiment was initiated on 16-week-old, field-grown plants. The plants were in early bloom, the stage when rotenoid content and leaf yield are approaching their highest level. The object of this experiment was to determine whether the rotenoids in artificially yellowed leaves were increased like those in naturally senescent leaves. Based on the results of the first experiment, one concentration of each of seven growth regulators and a water control treatment were selected for this experiment. Fifty milliliters of solution were sprayed onto each plant. An $8 \times 8$ Latin square design with one plant per plot was used. Nine days after treatment plants were scored for degree of yellowing, and leaf samples were collected for rotenoid assays. The rotenoid data were submitted to an analysis of variance and the treatment means ranked according to Duncan's Multiple Range Test (3).

Significant differences in total rotenoids existed among treatments. Dicamba and 2,4,5-T induced a highly significant increase in the percent of total rotenoids per unit of dry weight over those of the other treatments (table 2). The rotenoid content of plants treated with the other five growth regulators was not significantly different from the water-sprayed control plants.

The dicamba and 2,4,5-T treatments also produced the greatest degree of leaf yellowing. Plants treated with 2,4,5-TP, 2,4-D, and 4-CPA showed less intense leaf yellowing, and it was not associated with a change in percent total rotenoids. Foliage treated with water, 2,6-DA and MH-30 remained green.

\section{LEAF ROTHNOIDS AND SPECIFIC LEAF WHGHT}

In the two previous experiments we demonstrated that some growth regulators induce yellowing in Tephrosia leaves. In some cases, these color changes were associated with increases in total rotenoids per unit of dry leaf weight. A third experiment was carried out to determine simultaneously the effect of growth regulators on both rotenoid content and specific leaf weight (SLW). This experiment included 11 treatments replicated 8 times in a randomized block design. The treatments included three concentrations 
each of dicamba, MH-30 and 2,4,5-T, plus one concentration of 2,4-D and a water control. Plants 20 weeks old were used in this study. Each plant received $50 \mathrm{ml}$. of solution. Leaf samples for both rotenoid assays and SLW determinations were taken 1,3 , and 8 days after the spray treatments were applied.

The data on percentage of total rotenoids and SLW were submitted to analyses of variance and the means separated by Duncan's Multiple Range Test. The data were also submitted to a covariance analysis to determine whether the changes in percentage total rotenoids were associated with changes in SLW.

TABLE 2.-Percentage of total rotenoids per unit of dry weight in $T$. vogelii leaves in relation to degree of senescence, 8 days after treatment ${ }^{2}$

\begin{tabular}{l|c|c|c}
\hline \multicolumn{2}{c|}{ Growth regulator } & $\begin{array}{c}\text { Mean rotenoid } \\
\text { content }\end{array}$ & $\begin{array}{c}\text { Degree of } \\
\text { leaf serescence }\end{array}$ \\
\cline { 1 - 2 } Treatment & Concentration & Percent2 & Scord \\
Water control & MG-/titer & $3.11 \mathrm{a}$ & 0.0 \\
2,4,5-TP & - & $3.21 \mathrm{a}$ & 4.9 \\
4-CPA & 300 & $3.04 \mathrm{a}$ & 1.5 \\
2,4-D & 1,000 & $2.99 \mathrm{a}$ & 2.8 \\
2,6-DA & 450 & $2.96 \mathrm{a}$ & 0.0 \\
MH-30 & 450 & $2.76 \mathrm{a}$ & 0.0 \\
Dicamba & 4,500 & $3.90 \mathrm{~b}$ & 9.6 \\
2,4,5-T & 1,000 & $3.78 \mathrm{~b}$ & 7.5 \\
\hline
\end{tabular}

1 Data represent mean of 8 replications.

2 Means followed by same letter are not significantly different at the 1-percent level, according to Duncan's Multiple Range Test.

Senescence as judged by leaf color and scored on a 0-10 scale; $0=$ green (no yellowing) and $10=$ yellow.

The results of this experiment are summarized in table 3. No significant differences in SLW were found among treatments 1 day after spraying, but highly significant decreases in SLW were observed in several 2,4,5-T and dicamba treatments 3 and 8 days after spraying. No significant differences in percent total rotenoid content were observed among treatments until 8 days after spraying. Then, the treatments of $1,000 \mathrm{mg}$. per liter of dicamba and of 250 and $500 \mathrm{mg}$. per liter of 2,4,5-T were significantly higher than the $\mathrm{MH}-30$ and water control treatments.

The 8-day rotenoid data were adjusted for differences in SLW with a covariance analysis. The adjusted data indicated that treatments did not differ significantly in percent total rotenoids per unit dry leaf weight. According to the $r^{2}$ value obtained from the correlation coefficient between 
TABLE 3.-Specific leaf weight (SLW) and percent total rotenoids per unit of dry weight of T. vogelii leaves harvested 1,8 , and 8 days afler spraying with growth regulators

\begin{tabular}{|c|c|c|c|c|c|c|c|}
\hline \multicolumn{2}{|c|}{ Growth regulator } & \multicolumn{6}{|c|}{ Intervals of sampling after spraying ${ }^{1}$} \\
\hline \multirow{2}{*}{ Treatment } & \multirow{2}{*}{ Concentration } & \multicolumn{2}{|c|}{1 day } & \multicolumn{2}{|c|}{3 days } & \multicolumn{2}{|c|}{8 days } \\
\hline & & SLW2 & $\begin{array}{l}\text { Rote- } \\
\text { noids? }\end{array}$ & SLw? & $\begin{array}{l}\text { Rote- } \\
\text { noids }\end{array}$ & SLW' & Rotenoids' \\
\hline Water control & $\begin{array}{c}\text { Mg./liler } \\
-\end{array}$ & 100 & 100 & $100 \mathrm{ab}$ & 100 & $100 \mathrm{a}$ & $100 \mathrm{c}$ \\
\hline Dicamba & $\begin{array}{r}50 \\
500 \\
1,000\end{array}$ & $\begin{array}{r}95 \\
102 \\
95\end{array}$ & $\begin{array}{l}101 \\
102 \\
105\end{array}$ & $\begin{array}{l}93 \text { bcd } \\
94 \text { abcd } \\
88 \text { cde }\end{array}$ & $\begin{array}{r}102 \\
96 \\
112\end{array}$ & $\begin{array}{l}96 a b \\
89 a b \\
79 c\end{array}$ & $\begin{array}{l}114 \mathrm{bc} \\
121 \mathrm{abc} \\
142 \mathrm{ab}\end{array}$ \\
\hline $2,4,5-T$ & $\begin{array}{r}50 \\
250 \\
500\end{array}$ & $\begin{array}{r}100 \\
95 \\
93\end{array}$ & $\begin{array}{r}98 \\
102 \\
113\end{array}$ & $\begin{array}{l}97 \text { abc } \\
86 \text { de } \\
83 \text { e }\end{array}$ & $\begin{array}{l}103 \\
115 \\
113\end{array}$ & $\begin{array}{l}87 \mathrm{bc} \\
78 \mathrm{c} \\
78 \mathrm{c}\end{array}$ & $\begin{array}{l}123 \mathrm{abc} \\
146 \mathrm{a} \\
138 \mathrm{ab}\end{array}$ \\
\hline MH-30 & $\begin{array}{r}200 \\
1,000 \\
5,000\end{array}$ & $\begin{array}{r}98 \\
104 \\
95\end{array}$ & $\begin{array}{r}101 \\
101 \\
99\end{array}$ & $\begin{array}{l}95 \text { abcd } \\
103 \text { a } \\
97 \text { abc }\end{array}$ & $\begin{array}{r}101 \\
102 \\
96\end{array}$ & $\begin{array}{r}96 \mathrm{a} \\
100 \mathrm{a} \\
97 \mathrm{a}\end{array}$ & $\begin{array}{l}105 \mathrm{c} \\
108 \mathrm{ac} \\
110 \mathrm{c}\end{array}$ \\
\hline $2,4-\mathrm{D}$ & 50 & 100 & 110 & 94 abed & 107 & $92 \mathrm{ab}$ & 120 abc \\
\hline
\end{tabular}

1 Data presented as percentage of water-control treatment (actual mg. dry weight per twenty $3 / 8$-inch leaf disks of control treatment) 1,3 , and 8 days $=95.7,94.6$, and 103.6, respectively. Actual percent total rotenoids per unit of dry weight of water-control treatment 1,3 , and 8 days $=3.36,3.49$, and 2.67 , respectively.

2 Means not statistically different at 5-percent level of significance.

Means followed by same letter are not significantly different at the 1-percent level, according to Duncan's Multiple Range Test.

rotenoid content and SLW ( $r=0.975,9 \mathrm{df}$ ), 95 percent of the differences among treatments for percent total rotenoids was associated with differences in SLW.

\section{DISCUSSION}

Yellow leaf color resulting from natural and/or chemically induced senescence was associated with an increase in percent total rotenoids per unit of dry leaf weight in $T$. vogelii. Two growth regulators, dicamba and 2,4,5-T accelerated leaf senescence and significantly increased the percent rotenoids per unit of dry weight in the leaves. This increase in percentage rotenoids was associated with a decrease in specific leaf weight. The loss in specific leaf weight may have resulted from the lowering of the photosynthetic efficiency of the leaf, caused by a chlorophyll breakdown coupled 
with a simultaneous accelerated utilization of leaf metabolites. This is similar to the report by Hilton, Jansen, and Hull (4) which stated that, in general, phenoxy acids increase metabolic rates and lower photosynthetic efficiency.

It has been concluded from the available data that the growth regulators used in these studies did not increase the absolute accumulation of rotenoids in the Tephrosia leaf. Apparently during the process of natural or chemically induced senescence, leaf metabolites decrease, but the absolute amount of rotenoids remains constant. This causes a change in the ratio of rotenoids to specific leaf weight. Therefore, the percent total rotenoids per unit of leaf weight increases in senescent leaves without increasing rotenoid yield.

\section{SUMMARY}

$T$. volgelii leaves that were yellowed naturally by senescence or artificially by foliar applications of growth regulators showed significant increases in percent total rotenoids per unit of dry leaf weight. The growth regulators that most effectively accelerated leaf-yellowing were dicamba, 2,4,5-T, 2,4,5-TP, and 2,4-D. MH-30, 2,4,6-T amide, 2,6-DA, and 4-CPA failed to induce leaf-yellowing in $T$. vogelii. Leaf yellowing was accompanied by losses in dry leaf weight per unit area. This was assumed to be caused by the growth regulators lowering photosynthetic efficiencies and increasing metabolic rates, thereby lowering leaf reserves. It is concluded that leafyellowing per se did not change the absolute quantity of rotenoids per leaf; it only altered the ratio of total rotenoids to the total dry weight in a leaf.

\section{RESUMEN}

Hojas de $T$. vogelii, naturalmente amarillentas por su envejecimiento o artificicialmente amarilleadas al asperjarse con reguladores de crecimiento (fitohormonas) aumentaron significativamente su porcentaje de rotenoides por unidad de peso seco. Los reguladores de crecimiento que más efectivamente aceleraron el envejecimiento y amarilleo fueron el dicamba, el 2,4,5$\mathrm{T}$, el 2,4,5-TP y el 2,4-D, mientras que el $\mathrm{MH}-30$, el 2,4,6-T-amido, el 2,6-DA y el 4-CPA no lograron aumentar el porcentaje de rotenoides, ni inducir la amarillez de las hojas de T. vogelii. La amarillez de la hoja fue acompañada por una pérdida en el peso seco por unidad de área de la hoja. Se atribuye esta pérdida a que los reguladores de crecimiento, al disminuir la eficiencia fotosintética y aumentar el ritmo metabólico, también disminuyen las reservas de los tejidos de las hojas, con una consiguiente pérdida en el peso seco. Se concluye, pues, que la amarillez de la hoja de por sí no causó un aumento en la cantidad absoluta de los rotenoides por hoja, sino que sólo alteró la proporción de rotenoids totales en relación con el peso seco total de la hoja. 


\section{LITERATURE CITED}

1. Barnes, D. K., and Freyre, R. H. Recovery of natural insecticides from Tephrosia vogelii., III, An improved procedure for sampling and assaying rotenoid content in leaves, Econ. Bot: $21:$ : 93-8, 1967.

2. Barnes, D. K., Freyre, R. H., Higgins, J. J., and Martin, J. A., Rotenoid content and growth characteristics of Tephrosia vogelii as affected by latitude and within-row spacing, Crop Sci. 7: 93-5, 1967.

3. Duncan, D. B., Multiple range and multiple $F$ tests, Biomelrics 11: 1-42, 1955.

4. Hilton, J. L., Jansen, L, L., and Hull, H. M., Mechanisms of herbicide action, Ann. Rev. Plant Physiol 14: 353-84, 1963.

5. Irvine, J. E., and Freyre, R. H. Varietal differences in the rotenoid content of Tephrosia vogelii., Agron. J. 51: 664-5, 1959.

6. Irvine, J. E., and Freyre, R. H. Occurrence of rotenoids in some species of the genus Tephrosia, J. Agr. Food Chem. 7: 106-7, 1959.

7. Jones, M. A., Application of a modified red-color test for rotenone and related compounds to Derris and Lonchocarpus, J. Assoc. Offic. Agr. Chemists 28: 352-9, 1945. 